\title{
Lack of Consumer Awareness: A Major Challenge for Electricity Consumer Protection in Nigeria
}

\author{
Dahiru Jafaru Usman ${ }^{1,2}$, Nurli Yaacob ${ }^{1} \&$ Aspalella A. Rahman ${ }^{1}$ \\ ${ }^{1}$ School of Law, College of Law, Government and International Studies, Universiti Utara Malaysia, Sintok \\ Kedah, 06010, Malaysia \\ ${ }^{2}$ Department of Public Law, Faculty of Law, Bayero University Kano, P.M.B. 3011, Kano Nigeria \\ Correspondence: Dahiru Jafaru Usman, School of Law, College of Law, Government and International Studies, \\ Universiti Utara Malaysia, Sintok Kedah, 06010, Malaysia. Tel: 60-16-480-4431. E-mail: djafaru@gmail.com
}

Received: May 30, 2015 Accepted: July 7, 2015 Online Published: August 18, 2015

doi:10.5539/ass.v11n24p240 URL: http://dx.doi.org/10.5539/ass.v11n24p240

\begin{abstract}
Purpose: This study explores the challenges for consumer protection in the Nigerian deregulated electricity sector. The study argues that ignorant and unenlightened consumers are easy prey for exploitation in the marketplace. Educating the consumer minimizes consumer exploitation and enhances consumer protection.
\end{abstract}

Design/methodology/approach: The study is qualitative. Twenty in-depth semi-structured interviews were conducted with the relevant stakeholders involved in consumer protection and standard setting in the Nigerian electricity sector. The study adopted the Benner's Interpretive Phenomenology and explored the everyday practical experience and perspectives of the participants on the challenges of consumer protection. The analysis was thematically conducted and accordingly supported by sufficient excerpts.

Findings: The study found several challenges for consumer protection in the Nigerian electricity sector. Emphatically, the participants were unanimous on lack of awareness as the major challenge for the electricity consumers' protection.

Research limitations: The research participants were only staff from consumer protection and products standard setting agencies, academics, and heads of consumer organizations. Additionally, the paper only addressed the challenge of lack of awareness and the data collection constrained by funds paucity and difficulties in securing appointments with the busy participants.

Practical implications: The study suggests that consumer protection agencies need to do more in the area of consumer education and enlightenment otherwise the exploitation of the Nigerian electricity consumers will continue.

Originality/value: Consumer protection literature abounds. This study is, however, the first attempt at qualitatively exploring in-depth the challenges for electricity consumers in deregulated electricity sector. The study emphasized the value of consumer awareness for better consumer protection.

Paper type: Research Paper

Keywords: consumer awareness, consumer education, consumer ignorance, consumer protection, Nigerian electricity industry

\section{Background}

Nigeria like many countries has a legal and institutional framework for consumer protection. While the Consumer Protection Council Act, 1992 (hereinafter referred to as the CPC Act) is the overall Nigerian consumer protection statute for both the goods and services industries, other sector specific laws exist. The Electric Power Sector Reform Act, 2005 (hereinafter referred to as the EPSRA) for instance, is the electricity industry specific law. From the institutional perspectives, the CPC Act established the Consumer Protection Council (CPC) as the highest consumer protection agency to implement the provisions of the CPC Act and all other consumer protection laws for the betterment of consumers. Apart from the CPC, the Nigerian Electricity Regulatory Commission (NERC) is the electricity sector regulatory agency established by the EPSRA to superintend on the electricity industry. The mandates of the NERC include the protection of electricity consumers. Lack of 
consumer awareness on the existence of these legal and institutional arrangements is undeniably a problem for consumer protection especially in developing countries such as Nigeria. This lack of awareness is a big challenge for the consumer protection systems. With over one hundred seventy million people (WB, 2013; CIA, 2014; Ismail et al., 2012) and with a utility such as electricity in private hands, Nigeria is not exempted. Apart from Nigeria being a consumer economy (Ezeonyejiaku, 2015), the illiteracy level in the country stood at about 40 percent (CIA, 2014). A greater percentage of the Nigerian population is exploited and faces daunting challenges in getting its consumer rights protected. The lack of awareness may account for this challenge. Although the consumer exploitation happens in all sectors especially the deregulated industries such as the banking, the telecommunications (Atoki, 2015; Okon, 2015; Ogu, 2010; Oghojafor et al., 2014; Okwuke, 2014; Dada, 2013), the consumer exploitation is more worrying in the recently deregulated electricity industry where consumer rights violation is at an alarming proportion (Eshemitan, 2015; Opara, 2015). The industry is characterized by poor and epileptic electricity services provision, arbitrary and estimated billings, metering crisis, influx of substandard electricity gadgets and equipments as well as other consumer abuses (Kunle Kalejaye, 2013; Mbamalu \& Adeoye, 2014; Asu \& Osu, 2014; Ogunbanjo, 2014; Nwakaegho, 2015; Adekoya, 2014). According to the Director General of the CPC, complaints received by the CPC over consumer abuses in the electricity industry are the highest compared to complaints received from any other sector of the Nigerian economy (Opara, 2015; Eshemitan, 2015). Despite the existence of laws such as CPC Act and the EPSRA, and despite the established agencies such as the $\mathrm{CPC}$ and NERC, consumer rights abuses continue in the Nigerian electricity industry and have been a source of serious concerns. Notwithstanding the concerns generated by these consumer abuses, research on the level of consumer rights awareness is scarce in Nigeria.

Qualitative research is about deeper understanding of a phenomenon (Patton, 2002). But Studies are, however, scarce on the perception of relevant stakeholders especially consumer protection agencies, heads of consumer organization, etc. of the leading challenges of consumer protection in the developing countries. The need for a deeper and thorough understanding of the perception, feelings and experience of the relevant stakeholders involved in consumer protection and products standards setting in the Nigerian electricity sector prompted this research. The paper, therefore, investigated the understanding and the experiences of officials of the consumer protection and products standard setting agencies, and consumer experts in the work of consumer protection. Because of the unanimity of the participants on the lack of awareness as a major challenge of consumer protection, this paper examined in detail the lack of awareness and its sub-themes as a major challenge for consumer protection. The study aims at providing information and insight to policymakers and even the electricity service providers on the challenges of consumer protection and how best to improve in that regards. This research would assist immeasurably in advancing the course of the electricity consumers who suffer from poor and non-service in the electricity industry.

\section{Literature Review}

In business circle, morality and virtuous conducts such as honesty and integrity are not so important (McKecnie \& Akinbami, 2011; Barry, 1991; Cheffins, 1997). Profit at all cost is the driving motive (Zubizarreta \& Lang, 2015; Ponlanyi, 1997). In deregulated markets, private firms commit a lot of malpractices in pursuit of greater profits at the expense of the consumer (Ho \& Sin, 1988). In fact, evidence of market manipulations by private firms at the consumers' expense abounds (Andrews-speed et al., 2014; Evans, 2015; Jansson, 2010; Tiu Wright, Newman, \& Dennis, 2006). How different are business enterprises in Nigeria?

\subsection{Consumer Awareness}

According to Dickinson and Shaver (1982: 241) "consumer awareness is the first line of defense against consumer problem." To be informed, the consumer needs to be educated and enlightened (Chatterjee \& Sahoo, 2011). But from the literature, the lack of consumer awareness cut across all jurisdictions (Verhage, 1987; Agbonifoh \& Edoreh, 1986; Widdows et al., 1995; Donnelly \& White, 2013; CFPB, 2015; Anong \& Kunovskaya, 2013). Though the problem of low level of consumer awareness appears to be on the high side in developing countries. Recent Consumer International (CI) studies on the state of consumer protection across the globe confirmed that lack of consumer awareness is more a problem of the developing countries (CI, 2015; CI, 2013). Although the above literature is on the lack of awareness, this work is, however, different. While the methodology adopted by most of the studies reviewed was quantitative, the methodology of this study is qualitative. The research approach in the previous literature is, therefore, limited and cannot be utilized to gain deeper understanding of the phenomenon of consumer awareness a task this study carried out in view of the qualitative methodology adopted.

Consumer Ignorance has a profound effect on consumer protection (Monye, 2008; Kumar \& Rao, 2015). 
Existing studies on the topic are limited. While Kumar Rao (2015) focused on India and utilized quantitative methodology, Felicia (2008) talked superficially about consumer ignorance in Nigeria and her paper was conceptual and not empirical. In other words, consumer ignorance has not been studied in detail especially in the context of Nigeria. The current study being empirical would, therefore, fill that gap. Additionally, the complexities of goods and services and the way they are marketed today pose more challenges to the consumer (Chatterjee \& Sahoo, 2011; Hannigan, 1976; Merwe et al., 2014; Yuthayotin, 2015; Best \& Andreasen, 1977). Ignorant consumers not being experts find it difficult to ascertain the quality, standard, as well as the performance of these products. Consumer education becomes handy.

\subsection{Consumer Education}

Education increases consumers' awareness (Dickinson \& Shaver, 1982; Merwe et al., 2014). Globally, consumer education has been recognized by scholars, international organizations and institutions as a tool for the protection of the consumers from the deception widespread in the marketplace. Consumer education is considered a veritable tool for improving the lives and safety of the consumers and has been an important priority to both EU and the United Nations system (Steffens, 2010; Boush et al., 2009; Schuh \& Kitson, 2003; Brennan \& Ritters, 2003). It is in recognition of the value of consumer education that the United Nations Guidelines for Consumer Protection, 1985, declared consumer education as one of the eight consumer rights (Widdows et al., 1995; UN, 1985). In the same year, CI the global and leading consumer organization in collaboration with its Southeast Asian regional office created a standing committee on consumer education (Jensen, 1991). In the EU, consumer education is a legal right and integral to the EU consumer policy (Benn et al., 2003; Goldsmith \& Piscopo, 2014). By Article 153 of the Treaty of Amsterdam (EU, 1997), consumer education is among the general objectives of the EU consumer protection policy. Because of the value the EU attached to consumer education, the European Commission recently made raising consumer rights awareness and knowledge as the twin objectives behind the issuance of the European Consumer Agenda (EC, 2012). At the African level, the example of Botswana and Kenya are quite instructive. In Botswana, consumer education is incorporated into the secondary school and university educational curriculum since 1990 (Makela \& Peters, 2004). While consumer education is a priority to the UN, the EU and even in some African countries such as Botswana, it is not the case in the Nigerian context. Consumers need consumer education through both formal and informal means (Schuh \& Kitson, 2003). But consumer education is yet to be incorporated in the Nigeria's educational curriculum. The impacts of omitting consumer education in the education curriculum and the need for its incorporation would be revealed in the course of this study. In fact, scholarly literature on consumer education and the effects of lacking it especially in developing countries such as Nigeria are limited or scarce. This study, therefore, contributes in that regards.

Lack of consumer rights education and consciousness is according to Mollah (2014) a barrier that prevents the poor and other vulnerable members of the society from accessing justice in Bangladesh. The lack of education and consciousness led to the evolution of public interest litigation in Bangladesh. Public interest litigation is not institutionalized in Nigeria. Although Mollah's study is on a developing country, it is not on Nigeria. The methodology adopted by Mollah (2014) though qualitative, differs from our studies in approach in terms of qualitative methodology and data collection. While Mollah relied on secondary materials in published literature, case law, and internet sources, this study relied on both empirical data and secondary data respectively sourced through in-depth interviews and available literature.

\subsection{Consumer Information}

"Consumer information and education are key tools in consumer policy toolbox"(Thøgersen, 2005, p. 155). Information is a means of consumer empowerment (Thøgersen, 2005) but too much information leads to information overload and affects effective consumers' decision. Requisite consumer information is, however, vital for consumer empowerment and proper functioning of markets (Hayek, 1945; McKecnie \& Akinbami, 2011; Keller \& Staelin, 1987; Tiu Wright et al., 2006; Herbig \& Kramer, 1994; Schmitz, 2013). Howells (2005) believed that information plays a great role in consumer protection. Howell (2005) posits that " $\{c\}$ entral to the government's philosophy is the belief that information is the most efficient means of protecting consumers." This philosophy is more useful in countries where illiteracy is on the high side. In other words, the value of information to the consumers has been overlooked in consumer protection literature especially in developing countries hence the need to be studied in Nigerian setting. Further on the value of consumer information, Muris (1991) argues that price information for instance, is "fundamental" in shaping consumers' purchasing decision especially in a competitive environment. Widdows et al. (1995) share the same opinion. They consider price information "essential" in shaping consumer decision. Much as the consumer should be informed, he should not be overloaded as too much information confuses the consumer, erodes consumer confidence and satisfaction 
(Lee \& Lee, 2004; Sicilia \& Ruiz, 2010). In contrast, requisite consumer information as opposed to overload, is, however, useful in improving the purchasing decisions of consumers (Gibson, 1992). In terms of knowledge about the markets and its workings, the consumer is not a perfect match to the business enterprises. The gap between the consumers, and the suppliers and service providers in that regards is wide and such gap has been exploited by the businesses at the consumer expense (McKecnie \& Akinbami, 2011; University et al., 1975). In fact, information asymmetry and the imperfection of the market have been identified as factors that necessitate the need for consumer protection (McKecnie \& Akinbami, 2011). But evidence is scarce in the Nigerian context of how this asymmetry impacted on consumer exploitation.

Consumers lack knowledge of basic consumer laws and consumer rights. The problem of consumers not knowing their rights, or the existing consumer protection laws has been studied. From the literature reviewed the problem is not peculiar to developing countries but also the developed jurisdictions (Jones \& Boyer, 1971; Best \& Andreasen, 1977; Schmitz, 2013). Studies reveal that consumers even in developed jurisdictions such as the UK don't know their consumer rights, consumer responsibilities as well as the existing consumer protection laws (Schuh \& Kitson, 2003; Best \& Andreasen, 1977; Kitson et al., 2003; Schmitz, 2013). If this is the case of UK what happens in developing countries such as Nigeria? To the best of the knowledge of the researchers, studies are scarce on whether Nigerians know their rights, know the existing consumer protection laws. This study, therefore, contributes in that regards. It needs to be stressed however, that notwithstanding the findings of Kitson et al. (2003) and similar findings, that the impacts of consumer ignorance is not profound in the developed jurisdictions compared to the developing countries such as Nigeria. This is attributable to the level of education and awareness in both jurisdictions, and the culture of rights protection in the latter compared to the former. A deep understanding of the phenomenon of the study from the stakeholders in charge of handling these consumers' affairs would provide a large and valuable amount of information in the area of consumer education and awareness. With Nigeria being a developing country the findings of this study would add to existing body of knowledge on the level of consumer awareness, consumer education and how the lack of both is a challenge for consumer protection systems and consumer redress. The research findings would equally add to the body of knowledge in the African context because Nigeria being the most populous nation in the continent has more consumers than other African countries.

In summary, it is submitted that although extensive theoretical work exists on the issue of consumer protection and consumer redress, empirical evaluations are less common. Equally, literature is scarce on the level of consumer awareness in any deregulated sector in Nigeria which is one of the distinctive characteristics of this study. This study fills that gap empirically. Although as the collected data reveals the challenges varied, we limit our analysis to lack of awareness because consumer awareness is the first line of defense against consumer exploitation.

\section{Research Methodology}

Being qualitative, this study employed the purposive sampling technique for the identification and selection of the research participants. In so doing, persons involved in consumer protection and who have the requisite information on the challenges of consumer protection were selected. In fact, the ultimate impact of the research sample on the research findings necessitated the selection of public officers and other participants with the rich experience in the area of consumer protection. The twenty participants were, therefore, drawn from academics, heads of consumer organizations as well as staff from consumer education, surveillance and enforcement units of the relevant electricity consumer protection agencies. The agencies are the Consumer Protection Council (CPC), the Nigerian Electricity Regulatory Commission (NERC), the Standards Organization of Nigeria (SON) and the Legal Aid Council of Nigeria (LACON). Participants from CPC were chosen because CPC is the apex consumer protection body while participants from NERC were chosen because NERC is the electricity industry regulator and all Nigerians are consumers of electricity directly or indirectly. The other participants were equally purposefully selected from lawyers in the academics and heads of consumer organization who have been involved in consumer protection in the country. Overall, the participants were selected because they have the relevant experience and information, and are "potential sources of rich data" (Drew, 2014, p. 77) on the phenomenon of the research. The relevant information and experience of the participants assisted in the realization of the research objectives.

This study aims at a deeper understanding of the experience of the stakeholders in consumer protection. It is, therefore, phenomenological (Patton, 2002). According Patton (2002), a phenomenological study is one that "aims at gaining deeper understanding of the nature or meaning of our everyday experiences." Patton argues that if researchers are to achieve deeper understandings they need to gather data and must "undertake in-depth interview with people who have directly or indirectly experienced the phenomenon of interest; that is they have 
lived experience as opposed to secondhand experience,"(Patton, 2002). Based on Patton's recommendation, in-depth semi-structured interviews were conducted face-to-face by the corresponding author with the twenty participants using an open-ended question format within the interpretivist paradigm. According to Mason (2002) the interpretivist approach "... sees people as a primary data source" and also "seeks their perceptions ... the 'insider view', rather than imposing an 'outsider view." The interpretivist approach enabled the researchers to understand the experiences of the enforcement agencies, experts and heads of consumer organizations and how best to solve the challenges of consumer protection. The flexibility of the semi-structured interview enabled the corresponding author to observe and capture the real challenges faced by the consumer protection agencies in the area of consumer protection.

The in-depth, semi-structured interviews were conducted within 2 months (July-August 2014). Sixteen of the interviews were conducted at the participants' offices while the remaining four were at the residence of the participants. The duration of the interviews lasted between thirty minutes to one hour period. Some of the interview questions include "how do you rate the electricity consumers' knowledge and awareness of their rights?" "In your opinion what are the challenges for consumer protection in the Nigerian electricity industry?" The Interviews were audiotaped and transcribed by the corresponding author who conducted the interviews. For evidential purposes, validation and in to support the research findings (Sandelowski, 1994; Hatch, 2002), data excerpts from the transcribed responses on the main and sub-themes of the research are included.

Interview text editing could either be "standardized or preservationist," (Sandelowski, 1994). The "standardized" as opposed to the "preservationist" approach to text editing, was adopted in the analysis of the transcribed data. Distracting elements, and colloquial and spoken words such as "aaam," "waooh," "hmm" "ehnn" "well" "you know" "you understand" "eeehh" were excluded in the relevant excerpts from the interviews.

Benner's Interpretive Phenomenological (BIP) tradition is adopted in this research (Benner 1994). The adoption of BIP is justified because of its' emphasizes on exploring the everyday human practical experience and knowledge. BIP assists the researchers to explore the participants everyday practical experience and knowledge on the challenges of consumer protection (Gill, 2014). In conducting the analysis, the thematic approach of themes identification with sufficient excerpts support as advocated by Benner (1985b) was adopted. The adoption of the thematic analytical approach was justified because according to Gill (2014), it "necessitates creativity and imagination." The lack of awareness theme was used as the main theme with several other emerging sub-themes.

For credibility purposes, the in-depth interviews and other raw data were accurately transcribed and documented by the corresponding author. The authors scrutinized the main theme and the emerging sub-themes from the transcribed data before the production of the research findings. For a more rigorous analysis and in order to make the research findings more plausible, the collected data was triangulated using data sourced from scholarly works, institutional and government documents (Patton, 2002; Merriam, 2014). To guarantee transparency and dependability of the data collection, this study conducted an audit trail. This is to ensure that other researchers would make similar observations of the data (Patton, 2002).

\section{Results}

The qualitative analysis resulted in several categories of challenges of consumer protection. These include lack of awareness, funding, staffing, cultural and religious barriers, poverty, corruption, etc. But the lack of awareness was more striking, and all the participants were unanimous that lack of awareness constitutes the major challenge for consumer protection. While all the participants were unanimous on the lack of awareness, no such unanimity was found on the sub-themes. The main theme and the sub-themes are examined below.

\subsection{Lack of Awareness}

Consumer awareness reduces the chances of consumer exploitations in the marketplace. Information on consumer rights and the existing consumer protection and complaints processing avenues is valuable in consumer protection strategies (McChesney, 1990; Aaker \& Day, 1982). In fact, a better-informed consumer improves the functioning of markets (Blayac et al., 2014). But the lack of consumer awareness has been one of the major challenges for efficient consumer protection in developing countries (Ismail et al., 2012; Zakaria, 2015; Alsagoff, 2006; Anong \& Kunovskaya, 2013). In this study, the participants reported lack of awareness as a major challenge for consumer protection in the Nigerian deregulated electricity sector. From the analysis of the participants' responses on the main theme (lack of awareness), other sub-themes emerged from the Participant's responses. These include lack of consumer education; consumer ignorance; lack of sensitization; lack of consumers' knowledge of their rights and the existing consumer protection agencies; lack of consumer awareness of the existing redress avenues; the lack of consumers' awareness of the existing consumer protection 
laws; and the lack of legal awareness.

\subsubsection{Lack of Consumer Rights Knowledge and Awareness}

Consumers' appreciation of their right helps immensely in their protection. Lack of rights awareness is a problem for the consumer protection systems. When the consumers are not aware they have a right, they cannot demand it. The consumer knowledge of his a right is the first step towards asserting it. However, the participants reported lack of consumer rights knowledge and awareness as a challenge for consumer protection. Thirteen participants rated the consumers' knowledge and their awareness of their rights very low. Participant 15 believes that "the whole issue of consumer rights protection in Nigeria has to do with awareness, the awareness is still very, very low."

On this sub-theme, thirteen participants reported that consumers in Nigeria are not aware of their rights. According to Participant 1;

"Most of the consumers are not aware of their rights and the limitations of the suppliers. So there is need for the consumer to know what he is consuming."

The response of Participant 6 is equally instructive. According to the Participant, "most of the consumers are not aware that they even have a right to pursue in relation to electricity supply."

The participants report that the issue of consumers not knowing their rights is not only among the illiterates but even amongst the educated. According to Participant 9;

" $\{\mathrm{t}\}$ he consumers in Nigeria don’t even know their rights even the schooled ones (sic), those who even go to the universities."

According to Participant 13:

"The problem usually, there is general lack of public awareness about even the role of the regulator, even what is going on, your rights people do not actually appreciates their rights and even those that appreciate their rights sometimes you look at the cost actually."

\subsubsection{Ignorance of the Consumer}

Ignorance of the consumer has been a problem militating against effective consumer protection especially in developing countries. The Indian situation has been reported in scholarly papers (Kumar \& Rao, 2015). Six participants $(4,6,7,9,10$, and 18) in this study reported consumer ignorance as a challenge to consumer protection in the electricity industry. Putting ignorance as the first barrier for consumer protection Participant 9 argues that "the first one concerning the electricity as I said earlier is ignorance."

With the high level of illiteracy in Nigeria, several participants reported ignorance of the consumer as one of the challenges militating against effective consumer protection. In fact, some of the participants feel that the government is to be blamed for the consumer ignorance and information gap. According Participant 7:

"People don't know their rights across all types of services. There is a lot of ignorance. I understand some people are not educated, but you can still teach them their rights in their own languages. This is huge. My opinion is the Consumer Protection Council, and the government itself should hold themselves responsible for the gap in information with regards to consumer protection. It's a major problem."

Part of the consumer ignorance that is a challenge to consumer protection is the fact that the consumers do not know how to read the meters and the bills presented by the electricity service providers. This is one of the problems reported by Participant 4. According to the Participant;

"The consumers do not know how to read the meters, how to read the bills. You do not know what is written on a bill, you do not know how they calculate."

\subsubsection{Lack Sensitization}

The importance of sensitization has been stressed. As a sub-theme of lack of awareness, lack sensitization was reported by four participants $(1,3,8$, and 11$)$ as a major challenge for consumer protection in the Nigerian electricity industry in particular and the country, in general. According to Participant 1:

"I have already said there is lack of sensitization. Most consumers are not aware of their own rights. Lack of sensitization involves a lot of things, a consumer thinks he has no rights. Most of the consumers are not aware of their own rights."

Participant 3 equally added his voice to the issue of lack of sensitization. According to the Participant;

"I don't see the consumers having a challenge. If there would be a challenge is the issue of sensitization." 
Participant 11 also reported lack of sensitization. According to the Participant;

"Sensitization is very important. Because if the people are not aware of their rights and responsibilities as consumers, of course, problems would continue to arise day- in-day out. We have not been able to carry out an effective sensitization programme."

4.1.4 The Problem of Consumers Not Knowing the Consumer Protection Agencies and the Existing Redress Mechanism

Problem of consumers not knowing the existing consumer protection agency is global. Research for instance, has shown that there is a lack of awareness of the existence of consumer redress forum such as the small claims court in the US (URSIC, 1981). Evidence of the problem in the African continent abounds in Ghana one of the Nigeria's neighbor (CI, 2013a). In Nigeria, consumers also lack knowledge of the existing consumer protection laws and structures in the country (Sani \& Usman, 2014). This is one of the sub-themes of lack of awareness reported from the responses of nine participants $(2,4,5,6,8,10,11,12$ and13) interviews. The participants reported that the consumers don't know the existing avenues for complaints and redress. This lack of awareness is found even among the educated elites. According to Participant 3, "a lot of consumers even the educated ones are still not aware that there is an agency that can come in to help them." This is a big challenge on the consumer protection drive. In similar vein, Participant, 11 reported that;

"There is this problem; consumers are not aware of the existence of certain agencies of government like the Legal Aid Council, or like the Consumer Protection Council."

Participant 2 equally captures the point. According to him;

"My difficulty is that I am not aware of a redress mechanism for electricity consumers at the moment, and that has to evolve fast. As the industry is being re-organized, unbundled"

In fact, Participant 6 queried that "if the public is ignorant of the existence of an agency, in what way can you approach such agency?

Even where the consumers know the avenues, the problems of not knowing the functions of the organizations or agencies exist. According to Participant 10;

"Awareness of consumers on our functions is very, very low. All efforts in the past to make our work

known to the public have failed. ... the awareness seems to be very low."

Responding from the perspective of the electricity regulator, Participant 13 lamented the state of lack of awareness of the role the Nigerian Electricity Regulatory Commission can serve as the regulator of the electricity industry. According to the Participant;

"The problem, usually there is general lack of public awareness about even the role of the regulator, even what is going on, on your rights people do not actually appreciate their rights."

\subsubsection{Lack of Knowledge of the Existing Consumer Protection Laws}

The consumers don't seem to know even the laws that protect them and the institutions meant to enforce those laws. Three of the participants $(1,2$ and 6$)$ reported the problem of the consumer not knowing the law or where to go and who to approach as a challenge for consumer protection. Participant 2 bared his mind when he said,

"My feeling is that consumers do not generally know the laws that protect them, so they are generally unaware of the existence of the law. You find some level of knowledge among elites, educated elites, even within them you may find, you will find that although they know the law existed, don't know what it provides. Electricity is just been deregulated and I want to believe that people do not know the legal regime now."

In the same footing, Participant 6 stated that;

" $\{\mathrm{i}\} \mathrm{n}$ fact, the regulations are not even known to the public. And .... If the public are ignorant of the existence of any law that sought to protect them in what way would they rise and ask for their rights from the appropriate agency? This is the problem, and there are a lot of lapses in this direction."

Adding his voice Participant, 1 stated that it is "very ironical most of the laws that are to be enacted are already in existence only that people are not aware of it or lack of implementation."

\section{Discussion}

This study explored in-depth the perception and experience of stakeholders involved in consumer protection and standards setting in the deregulated electricity sector in Nigeria. The study seeks to assist the government and 
business community in drawing up policies and measures towards improving consumers' welfare in the country. The study is equally beneficially to the consumers in gingering them to know their rights and to demand the same. From the twenty face-to-face semi-structured interviews with officers of the relevant consumer protection agencies, consumer experts, and academics, the study found that consumer protection in the Nigerian electricity sector is plagued with a lot of challenges. These challenges include funding, staffing, corruption and lack of consumer awareness, and they militate against the consumer in getting the protection he deserves.

Drawing from the perspectives of scholars such as Howell (2005), Boush et al. (2009) Agbonifoh and Edoreh (1986) and consumer protection agencies such as CFPB (2015) on the vital role consumer education and information play in protecting consumers, it is safe to say that consumers in the Nigerian electricity industry have a long way to go. From the evaluation of the participants' responses, electricity consumers in Nigeria are not informed and educated on their rights. Without knowing their rights and without information one would not expect serious consumer activism. The assumption here is that when consumers have information there is likelihood they would use it. There is equally the tendency that when the consumers are aware of existing consumer protection laws they would take advantage of it (Hogarth \& English, 2002). Similarly, consumers' familiarity with the established consumer protection agencies raises the likelihood of consumers utilizing those agencies in solving their consumer grievances. Conversely, when consumers lack information, are unaware of consumer protection laws and the existing consumer protection agencies the possibility of utilizing these safeguards in solving their problems is zero. In fact, as Blayac et al. (2014) posited the lack of information would affect the proper functioning of the market and the consumer is the worst of it.

From the literature, lack of awareness is not only a Nigerian problem but a global one. It cut across the developed and developing world (CFPB, 2015; Agbonifoh \& Edoreh, 1986). The Nigerian situation is, however, striking. This study found that lack of consumer awareness that covers consumer ignorance, lack of consumer sensitization, the consumer not knowing the relevant consumer laws and the consumer protection agencies is the major challenge for effective consumer protection in the deregulated electricity industry. Research has shown that Consumer rights awareness safeguards consumers from exploitation (CI, 2015). The unanimity of the all the participants in this study (drawn from the public and private sectors) corroborates the impacts of lack awareness on consumer protection in the industry and by extension the entire economy. The research findings speak volumes about the extent of consumer protection in the Nigerian electricity industry and the country at large. It is contended that with the bulk of consumers being uneducated; not knowing their rights and the consumer protection laws as well as the channels to ventilate their grievance, they are easy prey to exploitation by the unscrupulous businesses. Deduced from the evaluation of the perspectives, experience and reactions of the Participants, raising the consumer awareness, will, therefore, minimize, if not prevent a lot of the consumer exploitations in the electricity industry. By implication, the consumers need to be educated, and aware of their rights and all the consumer protection safeguards. This is a vital tool for consumer protection. As suggested by Makela and Peters (2004) and Gallagher (2002) consumer education and awareness would assist in developing responsible business behavior in the Nigerian electricity market.

\section{Limitations and Suggestion for Future Research}

Although the study findings must be treated in line with its qualitative character as such not generalizable, nonetheless, the findings represent the state of consumer protection in the Nigerian electricity industry. It provides a picture of what obtains in other sectors as electricity consumers are consumers of other necessities of life. Additionally, the twenty respondents involved in this research were limited to academics, heads of consumer organizations, as well as staff from consumer education, surveillance and enforcement units of the relevant electricity consumer protection agencies. The sampled research participants did not involve the ordinary electricity consumers. This study is further limited because the paper focused on the issue of lack of awareness being the major identified challenge of consumer protection in the industry. It is, therefore, suggested that future studies can include the ordinary electricity consumers and can as well explore the other problems militating against the protection of electricity consumers and the general consumers in the country. It is further suggested that future studies may quantitatively investigate the lack of consumer awareness and the other challenges of consumer protection in the deregulated electricity sector and in other sectors of the economy.

\section{Conclusions}

The in-depth semi-structured interviews with stakeholders in the field of consumer protection revealed the perspective and the experience of the participants on the several challenges electricity consumers face. The findings of the study show that electricity consumers face several challenges that hinder them from getting protected from the exploitations in the marketplace. Lack of awareness appears to be the major challenge. It can 
be safely concluded that the electricity consumers being uneducated and lacking in consumer rights awareness, are vulnerable to exploitation. With utility deregulation deeply rooted in Nigerian utility sectors, increasing consumer awareness as recommended by Dickinson and Shaver (1982) should be the first priority and the primary goal of the government, the electricity firms and consumer advocates. When a consumer is not aware of his rights how can he assert such rights? In fact, he easily leaves what is due to him and the business enterprise bank on the lack of awareness to profit from the same. Consumer awareness will influence the status quo and make consumer assertive. This study, therefore, calls for consumer awareness and education in Nigeria. The consumers need to be educated, enlightened and sensitized. This is the responsibility of the government, the business enterprises as well as the consumer organizations. Involving the businesses is necessary unless the market is conspiring to keep the consumers ignorant. More so, the consumers should be informed about their rights, about the redress mechanisms and even the extant consumer protection laws. They need consumer education and enlightenment on how, where and who to approach with their complaints about any right violation. The inclusion of consumer education in the Nigeria education curriculum and the initiation of awareness programmes in the electronic and print media would help immensely. This if done, would raise the level of the electricity consumer protection in the country (Zakaria, 2015). The over 170 million Nigerians need protection as consumers as such they need to be educated and enlightened. The findings of this study would assist policymakers, the electricity service providers and consumer groups in Nigeria in planning and strategizing for better and efficient consumer protection. Additionally, the research findings would be beneficial to other African countries and other developing nations in appreciating the multiplier effects the lack of consumer awareness poses to consumer protection.

\section{References}

Aaker, D. A., \& Day, G. S. (1982). Consumerism. Simon and Schuster.

Adekoya, F. (2014). SON holds forum for maritime operators to check influx of fake goods. Retrieved from http://www.ngrguardiannews.com/business/industry-watch/187920-son-holds-forum-for-maritime-operators -to-check-influx-of-fake-goods

Agbonifoh, B. A., \& Edoreh, P. E. (1986). Consumer Awareness and Complaining Behaviour. European Journal of Marketing, 20(7), 43-49. http://dx.doi.org/10.1108/EUM0000000004655

Alsagoff, S. S. (2006). Consumer Protection Facing Globalisation: A Comparative Study Between United Kingdom and Malaysia. Jurnal Undang-Undang dan Masyarakat, 10, 79-95.

Andrews-speed, A. P. et al. (2014). Research Note Do the Power Sector Reforms in China Reflect the Interests of Consumers?, 158, 430-446.

Anong, S. T., \& Kunovskaya, I. (2013). M - finance and consumer redress for the unbanked in South Africa. International Journal of Consumer Studies, 37(4), 453-464. http://dx.doi.org/10.1111/ijcs.12014

Asu, S. O., \& Osu, F. (2014). Electricity Consumers Condemn Rising Estimated Bills. Retrieved from http://www.punchng.com/news/electricity-consumers-condemn-rising-estimated-bills/.

Atoki, D. (2015). The State of Consumer Rights Protection in Nigeria. Public Lecture.

Barry, N. (1991). The morality of business enterprise. David Hume Institute.

Benn, J., Brennan, C., \& Ritters, K. (2003). Consumer empowerment in consumer education. Experiences from educational and consumer studies of youngsters Consumer education in the UK: new developments in policy, strategy and implementation How to create tools to empower the consumer - the challeng, (June), 223-225.

Benner, P. (1994). Interpretive phenomenology: Embodiment, caring, and ethics in health and illness. Sage Publications.

Benner, P. (1985). Quality of life: A phenomenological perspective on explanation, prediction, and understanding in nursing science. Advances in Nursing Science, 8(1), 1-14. http://dx.doi.org/10.1097/00012272198510000-00004

Best, A., \& Andreasen, A. R. (1977). Consumer Response to Unsatisfactory Purchases: A Survey of Perceiving Defects, Voicing Complaints, and Obtaining Redress. Law \& Society Review, 11(4), 701-742. http://dx.doi.org/10.2307/3053179

Blayac, T., Bougette, P., \& Montet, C. (2014). How consumer information curtails market power in the funeral industry. European Journal of Law and Economics, 37(3), 421-437. http://dx.doi.org/10.1007/s10657-012- 
9350-3

Boush, D. M., Friestad, M., \& Wright, P. (2009). Deception in the Marketplace.

Brennan, C., \& Ritters, K. (2003). Consumer education in the UK: new developments in policy, strategy and implementation. International Journal of Consumer Studies, 27(3), 223-224. http://dx.doi.org/10.1046/j. 1470-6431.2003.00308_8.x

CFPB. (2015). Arbitration Study: Report to Congress, pursuant to Dodd-Frank Wall Street Reform and Consumer Protection Act $\$ 1028($ a), Consumer Finacial Protection Bureau.

Chatterjee, A., \& Sahoo, S. (2011). Consumer Protection: Problems and Prospects. Postmodern Openings, (7), 157-182.

Cheffins, B. R. (1997). Company law: theory, structure and operation. OUP Catalogue.

CI. (2013). The state of consumer protection around the world (Revised April, 2013).

CI. (2015). The State of Consumer Protection Survey 2014/2015, Consumer International.

CIA. (2014). World Fact Book, Africa: Nigeria. Retrieved from https://www.cia.gov/library/publications/ the-world-factbook/geos/ni.html.

Dada, A. (2013). FG May Prosecute Telecoms Firms for Poor Services. The Punch.

Dickinson, V. H., \& Shaver, J. P. (1982). A Test of Consumer Awareness for Adults. Journal of Consumer Affairs, 16(2), 241-260. http://dx.doi.org/10.1111/j.1745-6606.1982.tb00174.x.

Donnelly, M., \& White, F. (2013). Report on Irish Consumers' Awareness and Knowledge of Legal Rights.

Drew, H. (2014). Overcoming barriers: Qualitative interviews with German elites. The Electronic Journal of Business Research Methods, 12(2), 77-86.

EC. (2012). A European consumer agenda: boosting confidence and growth. Communication from the Commission to the European Parliament, the Council, the European Economic and Social Committee and the Committee of the Regions. Retrieved from http://ec.europa.eu/consumers/

Eshemitan, J. (2015). Complaints About Power Sector Highest In Nigeria - CPC. Daily Independent. Retrieved from http://dailyindependentnig.com/2015/05/complaints-power-sector-highest-nigeria-cpc/

EU. (1997). Treaty of Amsterdam amending the treaty on European Union, the treaties establishing the European Communities and related acts E. Union, ed. Official Journal C 340. Retrieved from http://eur-lex.europa.eu/en/treaties/dat/11997D/htm/

Evans, M. (2015). Regulating Electricity-Market Manipulation: A Proposal for a New Regulatory Regime to Proscribe All Forms of Manipulation. Mich. L. Rev, 113, 585.

Ezeonyejiaku, K. (2015). Cleric Tasks Buhari On Economy, Power, Others. The Guardian.

Gallagher, K. (2002). Consumer support networks: improving consumer advice in the UK. International Journal of Family Studies, 26, 228-238.

Gibson, L. (1992). Access to justice and consumer redress within a Single Market. Journal of Consumer Policy, 15(4), 407-415. http://dx.doi.org/10.1007/BF01014119.

Gill, M. J. (2014). The possibilities of phenomenology for organizational research. Organizational Research Methods. http://dx.doi.org/10.1177/1094428113518348

Goldsmith, E. B., \& Piscopo, S. (2014). Advances in consumer education: European initiatives. International Journal of Consumer Studies, 38(1), 52-61. http://dx.doi.org/10.1111/ijcs.12063

Hannigan, J. A. (1976). Newspaper Ombudsman and Consumer Complaints: An Empirical Assessment. The Law \& Soc'y Rev., 11, 679. http://dx.doi.org/10.2307/3053178

Hatch, J. A. (2002). Doing qualitative research in education settings. SUNY Press.

Hayek, F. A. (1945). The use of knowledge in society. The American economic review, 519-530.

Herbig, P. A., \& Kramer, H. (1994). The Effect of Information Overload on the Innovation Choice Process. Journal of Consumer Marketing, 11(2), 45-54. http://dx.doi.org/10.1108/07363769410058920

Ho, S., \& Sin, Y. (1988). Consumer Protection in China: The Current State of the Art. European Journal of Marketing, 22(1), 41-46. http://dx.doi.org/10.1108/EUM0000000005266 
Hogarth, J. M., \& English, M. P. (2002). Consumer complaints and redress : an important mechanism for protecting and empowering consumers, 1 (September), 217-226.

Howells, G. G., \& Weatherill, S. (2005). Consumer protection law (2nd ed.). Dartmouth Aldershot.

Ismail, R. et al. (2012). Consumer Right to Safe Product: The Application of Strict Criminal Liability in Product Safety Legislations in Malaysia. Journal of Social Sciences \& Humanities.

Jansson, E. (2010). Deregulation and the stakeholder model. Corporate Governance, 10(2), 129-139. http://dx.doi.org/10.1108/14720701011035657

Jensen, H. (1991). Consumer education as a parameter of consumer action in Latin America and the Caribbean. Journal of Consumer Policy, 14(2), 207-228. http://dx.doi.org/10.1007/BF00381919

Jones, M. G., \& Boyer, B. B. (1971). Improving the Quality of Justice in the Marketplace: The Need for Better Consumer Remedies. Geo. Wash. L. Rev., 40, 357.

Keller, K. L., \& Staelin, R. (1987). Effects of quality and quantity of information on decision effectiveness. Journal of consumer research, 200-213. http://dx.doi.org/10.1086/209106

Kitson, M., Dislere, V., \& Harrison, H. (2003). An investigative study of adult consumer education and lifelong learning needs in the United Kingdom and Latvia. International Journal of Consumer Studies, 27(3), 222. http://dx.doi.org/10.1046/j.1470-6431.2003.00308_6.x

Kumar, C. R., \& Rao, D. N. (2015). Major Developments towards Consumer Protection in India. International Journal of Research, 2(1), 853-860.

Kalejaye, K. (2013). Electricity Consumers to pay N50,000 for Pre-paid Metres. The Vanguard. Retrieved from http://www.vanguardngr.com/2013/04/electricity-consumers-to-pay-n50000-for-pre-paid-metres/

Lee, B., \& Lee, W. (2004). The effect of information overload on consumer choice quality in an on - line environment. Psychology \& Marketing, 21(3), 159-183. http://dx.doi.org/10.1002/mar.20000

Makela, C. J., \& Peters, S. (2004). Consumer education: creating consumer awareness among adolescents in Botswana. International Journal of Consumer Studies, 28(4), 379-387. http://dx.doi.org/10.1111/j.14706431.2004.00402.x.

Mason, J. (2002). Qualitative researching. Sage.

Mbamalu, M., \& Adeoye, T. (2014). Electricity: Crazy Bils, Epeileptic Supply put Question Mark on Power Road Map. The Guardian.

McChesney, F. S. (1990). Consumer Ignorance and Consumer Protection Law: Emprical Evidence from the FTC Funeral Rule. $J L \&$ Pol., $7,1$.

McKecnie, S., \& Akinbami, F. (2011). Financial services and consumer protection after the crisis. International Journal of Bank Marketing, 29(2), 134-147. http://dx.doi.org/10.1108/02652321111107620

Merriam, S. B. (2014). Qualitative research: A guide to design and implementation. John Wiley \& Sons.

Merwe, D. et al. (2014). Consumers' knowledge of textile label information: an exploratory investigation. International Journal of Consumer Studies, 38(1), 18-24. http://dx.doi.org/10.1111/ijcs. 12053

Mollah, A. H. (2014). Judicial activism and human rights in Bangladesh: a critique. International Journal of Law and Management, 56(6), 475-494. http://dx.doi.org/10.1108/IJLMA-07-2013-0029

Monye, F. (2008). Tips on Consumer Protection. Consumer Journal, 4, 160.

Muris, T. J. (1991). Economics and Consumer Protection. Antitrust Law Journal, 103-121.

Nwakaegho, T. (2015). Estimated billing: Consumers' pain, Discos' gain. Daily Times.

Oghojafor, B. E. et al. (2014). Determinants of customer satisfaction and loyalty in the Nigerian telecommunications industry. British Journal of Marketing Studies, 2(5), 67-83.

Ogu, I. A. (2010). Predatory Banking Practices in Nigeria. Daily Trust Newspaper.

Ogunbanjo, A. (2014). Consumers Need Meters, not High Estimated Bills. Daily Independent. Retrieved from http://dailyindependentnig.com/2014/11/consumers-need-meters-high-estimated-bills/.

Okon, A. (2015). CPC to Prosecute Companies for Consumer Rights Abuse. The Punch.

Okwuke, E. (2014). Quality of Service in 2014, Acid Test for NCC. The Daily Independent . 
Opara, S. (2015). Power Sector Consumer Complaints Highest in Nigeria - CPC. The Punch. Retrieved from $\mathrm{http}: / / w w w . p u n c h n g . c o m / n e w s /$ power-sector-consumer-complaints-highest-in-nigeria-cpc/

Patton, M. Q. (2002). Designing qualitative studies. Qualitative research and evaluation methods, 3, 230-246.

Ponlanyi, K. (1997). La gran transformación. Crítica del liberalismo económico.

Sandelowski, M. (1994). Focus on qualitative methods. The use of quotes in qualitative research. Research in Nursing \& Health, 17(6), 479-482. http://dx.doi.org/10.1002/nur.4770170611

Sani, M. S., \& Usman, U. (2014). Assessment of Indigenous Capacity in Telecommunications Technology in Nigeria,. International Conference on Governance 2014, Organized by the UUM Institute of Governance.

Schmitz, A. J. (2013). Access to Consumer Remedies in the Squeaky Wheel System. Pepperdine Law Review, 39(2).

Schuh, M., \& Kitson, M. (2003). Adult consumer education across Europe-redressing the market or reaching the vulnerable consumer. International Journal of Consumer Studies, 27(3), 221. http://dx.doi.org/10.1046/ j.1470-6431.2003.00308_5.x

Sicilia, M., \& Ruiz, S. (2010). The effects of the amount of information on cognitive responses in online purchasing tasks. Electronic Commerce Research and Applications, 9(2), 183-191. http://dx.doi.org/10.1016/j.elerap.2009.03.004

Steffens, H. (2010). OECD. (2009). Promoting Consumer Education-Trends, Policies and Good Practices. Paris: Organisation for Economic Co-operation and Development. Journal of Consumer Policy, 33(3), 291-292. http://dx.doi.org/10.1007/s10603-010-9133-6

Thøgersen, J. (2005). How may consumer policy empower consumers for sustainable lifestyles? Journal of Consumer Policy, 28(2), 143-177. http://dx.doi.org/10.1007/s10603-005-2982-8

Tiu Wright, L., Newman, A., \& Dennis, C. (2006). Enhancing consumer empowerment. European Journal of Marketing, 40(9/10), 925-935. http://dx.doi.org/10.1108/03090560610680934

UN. (1985). United Nations Guidelines of Consumer Protection U. Nations.

University, N. et al. (1975). Consumer protection-new hope following failure of civil and criminal remedies. Journal of Criminal Law and Criminology, 66(3), 271-285. http://dx.doi.org/10.2307/1142735

URSIC, M. (1981). Small Claims Court as a Consumer Remedy: Some Research Needs. Journal of Consumer Affairs, 15(2), 392-395. http://dx.doi.org/10.1111/j.1745-6606.1981.tb00721.x

Verhage, B. J. (1987). Knowing your rights: A cross-cultural study. European Journal of Marketing, 21(5), 70-75. http://dx.doi.org/10.1108/EUM0000000004698

WB. (2013). World Bank Economic Report: Nigeria (No. 1 May).

Widdows, R. et al. (1995). Consumer issues and consumer protection in Asia. Advancing the Consumer Interest, 12-17.

Yuthayotin, S. (2015). Procedural Mechanisms for Achieving Access to Justice. In Access to Justice in Transnational B2C E-Commerce (pp. 177-212). Springer International Publishing. http://dx.doi.org/10.1007/978-3-319-11131-5_6.

Zakaria, Z. (2015). Regulation of Cosmetics: What has Malaysia Learnt from the European System? Journal of Consumer Policy, 38(1), 39-59. http://dx.doi.org/10.1007/s10603-014-9271-3

Zubizarreta, J. H., \& Lang, K. (2015). The new global corporate law N. B. and M. B. Dumontier. State of Power 2015.

\section{Copyrights}

Copyright for this article is retained by the author(s), with first publication rights granted to the journal.

This is an open-access article distributed under the terms and conditions of the Creative Commons Attribution license (http://creativecommons.org/licenses/by/3.0/). 